\title{
Foreign-language influence on the morphological structure of dialects that were formed in the bilingual habitat
}

\author{
Gurbanova llahe \\ National Academy of Science of Azerbaijan, doctoral \\ gurbanovailahe@gmail.com
}

DOI:10.5901/mjss.2014.v5n22p27

\begin{abstract}
The purpose of this article is to find out whether there have been changes in the morphological structure of some dialects of the Azerbaijani language in the bilingual environment. Investigated the internal structure of any language. The structurally agglutinative Turkic languages, the segment force of which is vowel harmony, are more resistant to change than internally changing inflected languages. But some dialects were formed and developed in the bilingual and even polylingual environment. But does fairly close proximity to the morphological system of any dialect. The study shows the conservatism of the Turkic languages to some extent associated with agglutinative systems. In every language morphological structure and phonetic laws are interrelated and determine each other. Research shows foreign-language influence on morphological structure of dialects, it is first necessary to clarify whether there is influence in the phonetic level. Agglutination and vowel harmony always predetermined internal resistance of the Turkic languages .
\end{abstract}

Key words: dialects, investigate, morphological

\section{Introduction}

It is known that dialects are the most unique event in the language, the reasons of emerging of which still produces different thinking on the part of scientists. All reflections, despite their dissimilarity, give logical conclusion. Dialects were formed by localization of tribal languages in some areas, while preserving the ancient conservative elements. It should be noted that some tribes were often localized in the neighborhood of unrelated tribes. This, of course, led to the development of this dialect in the bilingual environment. Mutual borrowing of lexical units itself is evident in languages, especially neighboring. As culture of the peoples is both historical and social phenomenon. Finding its origins in the most remote places of early maturation of each ethnic group, the culture in its development absorbed all non-alien, doing it own very harmoniously.

For example, all people, once neighboring Turkic tribes, took from the ancient Turks the method of cooking dolma or yogurt. Quite frankly, these people consider these cultural phenomena own, without even knowing about it borrowed nature and not guessing about the origin of these lexical units. Whereas the ancient Turks well mastered processing of dairy products, divided the sour milk in fat (йогурт от слова йог//йаг-жир, масло) and not fatty- ayran (seceded). Or take, for example, culinary arts of cooking dolma (filled). The name of dish itself speaks on the process of cooking. Ethno-linguistic analysis of the names of dishes shows that the name of the dishes in the lexicon of ancient Turks is formed according to the process of cooking. Moreover, these names include both the process and the state. There are many examples: buglama (steam and fresh), khashlama (stewing and brewing), demleme (brew and brewing), basdirma. The material collected from the dialects give hundreds of examples.

The same thing can be said about the opposite influence. Some names of the dishes in the Azerbaijani dialects were obtained from neighboring languages. For example, names such dishes as cikhirtma, alsoqulakh and others from Georgian, surfili from languages of the Caucasian peoples.

In such Azerbaijani dialects as Gakh, Sheki, Guba, Kusar the ancient Turkic elements preserved much stronger than in other dialects and sub-dialects of Azerbaijan. Why is that? After all these dialects developed not only in the bilingual but even in semi linguistic environment. We know from history that such ancient Turkic tribes as the Khazars, Pechenegs, Sabirs and others appeared in the North Caucasus in the early centuries of our era. For many centuries, these Turkic tribes were located in these regions. Cultural and linguistic ties occurring in these regions, reflected primarily on vocabulary. 
Generally, we can say that the vocabulary of above-mentioned dialects can be divided into two parts: the ancient Turkic and vocabulary borrowed from the language of the Caucasian peoples.

\section{Method}

To thoroughly investigate this research question, was used a comparative-historical, comparative and statistical methods.

\section{Materials}

The study was conducted in the various dialects of the Azerbaijani language. The main accomplice served "Dialectological dictionary Azerbaijani language." (Institutu, 2003)

Survey was carried out among different dialects by Azerbaijan. Many words used by the older generation, representatives are not clear under 50 years. Vocabulary covered all povdenevnuyu life.

\section{Procedure}

Firstly, the survey and the study was approved by the Division of dialectology and language history of the National Academy of Sciences of Azerbaijan. Then as it was approved in the main workshop of the Institute.

\section{Results}

The matter is fact, that the scientific importance of this issue is that the findings made in the course of the study can be applied the study of intercultural and linguistic facts, as well as dialects. The study revealed the following findings: a large number of mutual lexical borrowing, especially in the field of culture, some influence on foreign language phonetics of Azerbaijani language dialects, but any change in the grammatical structure of dialects has not been found.

\section{Foreign-language influence on the formation of dialects}

Same definitely can be said about phonetics dialects. Culture and language are interconnected and it can be said even that in some dialogue. Saussure also notes that ethnicity, language and culture are interrelated and linguistics is in contact with ethnology, that is, all these links that exist between the history of race and ethnicity and history of language are reflected in its language and this in turn generates a nation. ( Coccюp, 1999, 28)

We think that it is difficult not to agree with Saussure. Culture of a nation is reflected in its language, which like a mirror reflects the history of the ethnic group. Words of M.Shiraliyev about differentiation of dialects confirm our idea:

But when determining dialect system of Azerbaijani language it is not enough to come from one territorial or structural commonality or level of understanding of speakers of dialects or dialects. We must also consider the cultural and historical circumstances. ( Ширалиев, 1983, 6)

As we said, the vocabulary is the first tier of language, which primarily responds to any extralinguistic events. Phonetic tier albeit slowly, but also reflects the changes. Do the changes in the phonetic tier impact on tier morphological? Famous linguist Sapir affecting theme interconnectedness of phonetic and morphological processes noted:

Inflected language like Latin or Greek, uses the fusion method and this fusion is inherent both as internal psychological and as well as external phonetic significance ( Сепир, 1934, 106)

We think that it depends on how these changes deeply affect phonetic layer. If the matter is a phonetic transition that progress in any language, it is unlikely that they somehow affect the morphology. But phonetic laws, such as vowel harmony directly related to the morphological structure of the language, i.e. agglutination. Many linguists touched this topic. For example, Baudouin de Courtenay noted that vowel harmony is used as a means of derivational morphology. He is also looking for a vowel harmony in the morphological structure of the Ural-Altaic languages. (Kurtene, 2014, 102)

This hypothesis is supported by other scientists later. Russian linguist Vinagradov writes that the only vowel harmony in Turkic languages acts as forming of phonological structure of language. He notes:

All languages of the world consist of words and in all languages the words are not intertwined. In every language the word integrity is observed in different ways. All of these methods we name accent of words. The accent is not equivalent to emphasis. We name the accent all prosodic means which form the word $A$ and distinguish it from the word $B$. The main prosodic means we can call emphasis and vowel harmony ... (Винаградов, 1970, 116) 
Vinogradov also notes that vowel harmony not accidentally acts as a segment force in the Turkic languages. .. As a result, vowel harmony causes conservation of axial paradigm. Thus, structural bonds appear in two levels ( Винаградов, 1970)

On this occasion Reformatsky writes: Vowel harmony is a super segmental force, and it acts on integrity. As a fundamental structural event it affects not only the phonetic tier, but morphological tier, too. ( Реформатский, 1970, 106)

Sapir also thought the morphological differentiation of the main languages of their hallmark:

... We can say that all languages are different from each other, but some differ significantly more than others, and this is tantamount to saying that it is possible to ungroup them morphologically. (Сепир, 1934, 94)

Shiraliyev however notes that in some Azerbaijani dialects and patios sometimes one feels the influence of other languages and this also applies to lexical and morphological formation.

But he does not bring the credible evidence to support the presence of foreign-language influence on the grammatical structure of the Azerbaijani language and its dialects.(говоры)_ The author gives examples of violation of the principle of integrity and uniformity of the root in the northern and eastern dialect groups. For example: ata-atan-atouz; mən-mə:; sənsə :: other. (Ширалиев, 1983, 66)

But as we can see from the examples, it is not a violation of the integrity of the root but the principle of labialization that is inherent in all Turkic languages of Kipchak group. These changes can not affect the structure of the language. Labialization and de-labialization are phonetic phenomena that occur in all Turkic languages. However, here we can talk about some fusion. On rare fusion, occurring in dialect of Azerbaijani language, we will talk later below.

We appealed to the facts of Derbent dialect of Azerbaijani langauge. As it is known Derbent is the main city of Dagestan Federal Republic. That is, this dialect of Azerbaijani language is completely surrounded by Avar and other languages of the North Caucasus. Anyway, this dialect is also somewhat isolated from the literary Azerbaijani language. We think that the studied dialect can clearly display how real is the foreign-language impact on morphological structure of dialects being in the bilingual environment. According to our survey, we found that the word-formative process involves not only affixes similar to literary Azerbaijani language, but also the ancient Turkic morphemes that have long fallen into disuse in the literary language. For example, affixes such as -ığliglüg; -agləgleg; -çağ;-ilılulü; are consistent with affixes of literary language. (Institutu, 2009, 44) Here, for example, the affix mlüm corresponds to affix nlün of literary language. Alternation of phonemes $\mathrm{m} / \mathrm{h}$ characteristic for phonology of all Turkic languages. As for the affix-an (biç-an, ağart-an), which is not found in the Azerbaijani literary language now, then this affix Sevortyan noted its antiquity, particular spreading in the Kipchak group of Turkic languages. ( Севортян, 1966 , 322)

Another ancient affix actively serving in the word-formative process of Derbent dialect is mac $\backslash$ maş $\backslash$ bac. (Institutu, 2009, 44). This affix also bears traces of ancient Turkic language. Demirchizade, having explored the ancient epic "Kitabi Dede Korkut, " especially notes the given affix. ( Dəmirçizadə, 1959 66)

We have to note also that these ancient affixes have their parallels in other Turkic languages. According to our estimates, more than a dozen affixes involved in word-formative dialect, refers specifically to ancient stratum of Turkic language.

As we can see, foreign language influence on derivation process in the Derbent dialect of Azerbaijani language is not observed. Conversely, some isolation from the literary language helped to preserve the most ancient elements in dialect. Researcher of Azerbaijani language dialects being in semi-linguistic environment, such as Guba-Derbent dialects Kubra Guliyeva in the conclusion of her research leads to the following conclusions:

Descriptive, comparative historical and etymological analysis of facts once again demonstrated that the possibility of preserving by dialects and sub-dialects ancient the phonetic, grammatical and lexical elements in strange environment of other language, its purity of specifics are limitless. These dialects and sub-dialects, being in a foreign environment, to a certain extent are isolated from the development of the literary language, such as dialects and sub-dialects of Azerbaijani language in the territory of Dagestan FR, Georgia. ( Кубра, 2007, 135)

The same opinion is shared by the authors of the monograph. (Institutu, 2009)

We continued to study and refereed to grammatical suffixes. As is known, there are six cases in the literary Azerbaijani language. Derbent dialect also has six cases. In practice, except for some phonetic transitions the suffixes of cases coincide with the literary one. But expressing fractional numbers, the locative case acts instead of the original case. N.Dmitriyev thought that it was the result of the historical process in the language. He considered the original case as secondary and the locative case primary. ( Дмитриев, 1940, 74-75) 
Sometimes, in this dialect dative case acts instead of local and original cases. This property has been registered in some other dialects and in the ancient epic "Dede Korkut» (Dəmirçizadə, 1959, 295).

\section{Tables}

Remarkably, in this region, with the predicate expression the analytical way is used. For example:

\begin{tabular}{|l|l|}
\hline literary language & Derbent dialect \\
\hline Evdiniz(öydəsiniz)- & öydə varsuz \\
\hline Ağzındadır & agzında var \\
\hline gəl & gələ var \\
\hline
\end{tabular}

The same trend can be seen in the Borchali dialect of Azerbaijani language. This dialect is also on the territory of Georgia and of course, to some extent isolated from the literary Azerbaijani language. As Derbent dialect Borchali dialect is also surrounded by foreign language, in this case the Georgian language. But both dialects in this case, i.e., in the case of predicative expressions analytically, represent one of the most ancient syntax ways of the ancient Turkic language. As correctly noted by Sapir:

"Language changes not only gradually, but steadily, it unknowingly moves from one type to another. ( Сепир, 1934, 95)

Of course, the above quotes by Kubra Guliyeva that isolated dialects from the literary language are less exposed to the influence of literary and logically, they longer retain ancient elements, are quite justified. We think that the words of the famous linguist Sapir most accurately express the situation:

"It's as if the situation is that in which something pluperfect era of irresponsible mind of tribe made hastily inventory of their experience, confided this precocious classification that does not permit review and gave the heirs of their language the knowledge. In that, they have ceased to believe, but which they cannot overturn. Dogma, attributed by tradition to a steady performance, become ossified formalism. "( Сепир, 1934)

So, based on the findings arising from the research of the dialects of Azerbaijani language, especially those dialects, which in one way or another are in the bilingual habitat, it can be argued that the impact of foreign language on grammatical structure of dialects was not found. However, in the literature we can find such statements that in Derbend dialect most visual elements of Kipchak dialect are associated with the effect of Kumyk language, the closest dialect, on this dialect. (Institutu, 2009)

Kumyk language, however, included in the Kipchak group of Turkic languages. But carefully researching the history of the area, it appears that such ancient Turkic tribes like the Khazars, Pechenegs, Sabirs and others appeared in the North Caucasus in the early centuries of our era. ( Артамонов, 1962)

That is, formation of Derbent dialect of Azerbaijani language and Kumyk language proceeded to independently from each other.

As for some fusion, rarely seen in the dialects can be explained otherwise.

Sapir wrote on this subject:

"however, the presence of fusion does not seem sufficiently clear indication of inflectional process ... our mind requires a fulcrum. If it cannot bear on individual formative elements, it more resolutely endeavor to reach the whole word as a whole. Such a word, goodness illustrates agglutination, books - regular fusion, depth - irregular fusion, gees - symbolic fusion ( Сепир, 1934, 104)

The fact that many dialects are the main repository, even one can say treasury of the prehistoric elements of any language. Whatever cannot be found in the written records, can be found in the dialects and sub-dialects carefully investigated. For example, many of the facts of the dialects and sub-dialects of the Azerbaijani language in the comparative analysis find its analogy in other Turkic languages, at first glance, which seem so far away in the distance. It is known that the differentiation between the dialects and sub-dialects of different languages manifests itself in varying degrees depending on the language. In fact, sometimes, even the distance plays a smallest role in differentiation. As distant from each other in a larger distance 
than the same German dialects and sub-dialects, the independent Turkic languages differ from each other least. We think that the factors contributing to this situation primarily are divided into two basic camps, which are interconnected and define each other. The first principle is linguistic, that is the mater is the internal structure of any language. Turkic languages being agglutinative in its structure, the segment force of which is vowel harmony, are more resistant to change than internally changing inflected languages. This determines the interconnectedness of Turkic languages among themselves and particularly between their dialects in separate.

But some dialects were formed and developed in the bilingual and even polylingual environment. That, of course, contributed adstrate and substrate in these dialects. We have already mentioned that the conservatism of the Turkic languages, in some extent is associated with agglutinative systems. According to our firm belief, in every language morphological structure and phonetic laws are interrelated and determine each other. In other words, vowel harmony of Turkic languages is directly linked to the agglutination. Many well-known linguists and specialists in Turkic philology in particular had reports on this issue.

We think that inter-level communication in language is tightly linked. Agglutination and vowel harmony always predetermined internal firmness of the Turkic languages.

\section{References}

Dəmirçizadə. (1960). Kitabi Dədə Qorqud dastanlarının dili. Baku: Maarif.

Institutu, A. D. (2009). Azərbaycan dilinin Dərbənd dialekti. Baku: Elm.

Kurtene, B. D. (2014). Ümumi Dilçilik üzrə əsərləri. Baku: Prestij çap evi.

Артамонов. (1962). История Хазар. Ленинград: Государственный Эрмитаж.

Винаградов. (1970). Сингамонизм и фонология слова. Фрунзе: Илим.

Дмитриев. (1940). Граматика кумыкского языка. Москва-Лениниград: Наука.

Кубра, К. (2007). Древнетюркский пласт Кубинско_Дербентского диалекта. Баку: Нурлан.

Реформатский. (1970). Сингармонизм как проблема фонологии и общей лингвистики. Фрунзе: Илим.

Севортян. (1966). Аффриксы именного словообразования в азербайджанском языке. Москва: Наука.

Сепир, Э. (1934). Язык. Москва Ленинград: Госурарственное Социально-Экономическое Издательство.

Соссюр, Ф.д. (1999). Курс общей лингвистики. Екатеринбург: Издательство Уральского Университета.

Ширалиев. (1983). Диалекты и говоры азербайджанского языка. Баку: Элм.

İnstitutu, A. M. (2003). Azərbaycan Dialektoloji lüğəti. Ankara: Türk Dil Kurumu Yayınları . 